\title{
MIT POŁUDNIA JAKO KONTRAPUNKT DLA OPOZYCJI WSCHÓD - ZACHÓD I PODSTAWA MITU EUROPY ŚRODKOWEJ
}

\author{
JAGODA WIERZEJSKA ${ }^{1}$ \\ (Warszawa)
}

Słowa kluczowe: Południe, mit, Austro-Węgry, Dunaj, ruiny, Cyganie

Keywords: South, myth, Austria-Hungary, Danube, ruins, Gypsies

\begin{abstract}
Abstrakt: Jagoda Wierzejska, MIT POŁUDNIA JAKO KONTRAPUNKT DLA OPOZYCJI WSCHÓD - ZACHÓD I PODSTAWA MITU EUROPY ŚRODKOWEJ. „PORÓWNANIA” 11, 2012, Vol. XI, s. 71-85, ISSN 1722-165X. Artykuł dotyczy prób myślenia o Europie Środkowej i dowartościowania jej w związku z kategorią Południa, czyli zmianą horyzontalnego, równoleżnikowego paradygmatu, narzucającego konieczność definiowania Europy Środkowej przez odniesienie do Wschodu i Zachodu, na paradygmat wertykalny, południkowy, umożliwiający stworzenie mitu środkowoeuropejskiego, w którym głównym punktem odniesienia są nacje bałkańskie. Spojrzenie na Południe jako na kontrapunkt dla opozycji Wschód - Zachód ma swoje antecedencje w latach 30. XX w. W prozie polskiej powstałej po $1989 \mathrm{r}$., zwłaszcza utworach Andrzeja Stasiuka, można wskazać elementy mitu Południa jako podstawy mitu Europy Środkowej, takie jak: motywy cekańskie, idea cywilizacji naddunajskiej, kreacja Cyganów na bohaterów kulturowych i specyficznie przekształcony topos „poezji ruin”.
\end{abstract}

Abstract: Jagoda Wierzejska, THE MYTH OF THE SOUTH AS A COUNTERPOINT TO THE OPPOSITION OF EAST - WEST AND A BASIS OF THE MYTH OF CENTRAL EUROPE. „PORÓWNANIA" 11, 2012, Vol. XI, pp. 71-85, ISSN 1722-165X.The article aims at considering Central Europe and appreciating it in connection with the category of the South. This means the change from the horizontal, parallel paradigm, which imposes the necessity of defining Central Europe by reference to the East and West, to the vertical, meridian paradigm, enabling the creation of the myth of Central Europe, where the main reference point are the Balkan nations. A look at the South as a counterpoint to the opposition East - West has its antecedents in the 30s of the $20^{\text {th }}$ century. In the Polish prose created after 1989, especially in the works of Andrzej Stasiuk, it is possible to

\footnotetext{
${ }^{1}$ Correspondence Address: j.wierzejska@uw.edu.pl
} 
specify the elements of the myth of the South as the basis of the myth of Central Europe, such as: themes of Austria-Hungary, the idea of civilization of the Danube, the creation of the Gypsies as cultural heroes and the specifically transformed topos of the "poetry of ruins".

W XVIII, a zwłaszcza w XIX stuleciu, wielu zachodnich myślicieli głosiło tezy na temat nieoryginalności kultury Słowian, którzy skazani są jakoby na powielanie wzorów płynących od „starszych”, czytaj: „lepszych”, a w związku z tym „pełnoprawnych" narodów europejskich. Przekonywano, że Słowianie nie potrafią osiągnąć obowiązującego na Zachodzie stanu wiedzy ani wykształcić równie wartościowych jak tamtejsze form nauki i sztuki. Przyczyny takiego stanu rzeczy miały się wiązać z geograficzno-klimatycznymi realiami Słowiańszczyzny oraz psychofizycznymi uwarunkowaniami jej mieszkańców. Wskazywano na agrarny tryb życia jako na źródło „niższości” Słowian. Często wspominano też o wynikającej z agraryzmu przewadze żywiołu chłopskiego na tutejszych ziemiach oraz słowiańskiej „bierności” i „nijakości”. Według Georga W. F. Hegla na przykład, rolnictwo, zakładające prymat sił przyrody, spowodowało u Słowian wolniejszy rozwój podmiotowej jaźni i potrzeby uczestnictwa w strukturach państwowych². Dlatego Słowianie nie stanowili dla filozofa interesującego przedmiotu rozważań, bo choć część z nich "została pozyskana dla ducha zachodniego”, cała reszta „ludzka masa” 3 - nie wystąpiła jeszcze jako samodzielny czynnik w procesie rozwijania się rozumu w dziejach.

U podstaw tego typu dyskursu leżało przekonanie, że kultura Okcydentu stanowi wzór, który rozprzestrzenia się, słabnąc na kresach swojego oddziaływania, zgodnie z zasadą: im dalej od źródła, tym mniej elementów ze źródłem wspólnych. W tak pomyślanym świecie, Słowiańszczyźnie usytuowanej między państwami zachodnioeuropejskimi a Rosją musiała przypaść rola naśladowcy, nieudolnie kopiującego wzorce pochodzące z kulturowego centrum. Dla Europy Świętego Przymierza Rosja, notabene kojarzona raczej z Orientem i azjatycką egzotyką niż słowiańskością, była jedynym poważnym wschodnim partnerem; cała reszta Słowiańszczyzny stanowiła po prostu jej obrzeża. Trudno się dziwić, że w tej sytuacji chwytliwa stała się teza niemieckiego historyka, Leopolda von Rankego, zgodnie z którą Europa to skłócone małżeństwo romańsko-germańskie, a element słowiański jest w niej intruzem ${ }^{4}$. Atrybuty przypisywane Słowianom i wytworom ich kultury przez zachodnich Europejczyków sugerowały wszak, że

\footnotetext{
2 Por. G. W. F. Hegel, Wyktady z filozofii dziejów, t. 2. Przeł. J. Grabowski, A. Landman. Warszawa 1958, s. 307.

${ }^{3}$ Oba cytaty pochodzą z: ibidem, s. 205.

4 Por. L. Cs. Szabó, Trzy siostry. Europa Środkowa w chrześcijańskim średniowieczu. Przeł. E. Miszewska-Michalewicz. „Więź” 1989, nr 11-12, s. 112.
} 
tutejsza część Europy jest do Zachodu niby podobna, ale jednocześnie nieskończenie od niego gorsza.

Owe negatywne stereotypy w specyficzny sposób próbował przewartościować Adam Mickiewicz w wykładach paryskich. Poeta podkreślał, że Słowianie są zakorzenieni $\mathrm{w}$ mitach i legendach, a w konsekwencji usytuowani niejako poza czasem. Pokazywał też, że oficjalna historia ma niszczący wpływ na losy nieustannie podbijanej Słowiańszczyzny, ponieważ grzebie je pod powłoką wizji dziejów, ukształtowaną przez zwycięzców, i skazuje na zapomnienie. W optyce autora Dziadów Słowianie u zarania nie mieli „słowa, które głosi prawdy wyższego

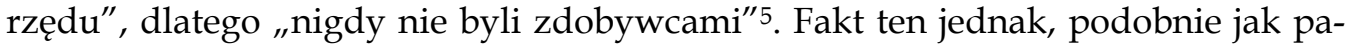
sywność i brak jedności Słowian, a także gotowość na śmierć, upodabniająca ich do Umierającego gladiatora ${ }^{6}$, stanowią potencjał możliwy do zrealizowania w przyszłości?.

Jak wynika z ustaleń Marii Bobrownickiej, kierunek argumentacji Mickiewicza nie był w owym czasie wyjątkowy. Wielu słowianofilów zachodnio- i południowosłowiańskich XIX stulecia (choć w XVIII wieku nie brakowało prekursorów, a w XX - kontynuatorów ich myśli) przyjęło stereotyp antytezy słowiańskoeuropejskiej i w rezultacie nie uchroniło się od kompleksu niższości, będącego logicznym następstwem częściowego choćby uwewnętrznienia zaprezentowanej kategoryzacji ${ }^{8}$ Z jednej strony, owi słowianofile eliminowali niektóre składniki strukturalne własnej tradycji narodowej przez jej uludowienie, usytuowanie w polu semantycznym takich pojęć, jak „bierność” i „zniewolenie” oraz oparcie na legendzie zamiast na historii. W ten sposób tworzyli mit słowiański (to znaczy mit wspólnoty Słowian - jednolitej, acz często pomijającej Rosjan), ale jednocześnie ujawniali swe poczucie gorszości od Europy Zachodniej, ufundowanej na tradycji antycznej i judeochrześcijańskiej, a pośrednio także od potężnej, niehamującej imperialnych zapędów Rosji. Z drugiej strony, wykształcili oni różne koncepty mesjanistyczne - czasem laickie, czasem religijne, skontaminowane z martyrologicznym przeświadczeniem o wartości ofiary - które pełniły rolę kompensacyjną $\mathrm{w}$ stosunku do wspomnianego poczucia gorszości, ponieważ moralnie wywyż-

${ }^{5}$ A. Mickiewicz, Dzieła, t. 8 (Literatura stowiańska). Warszawa 1955, s. 68.

${ }^{6}$ Mickiewicz uważał, że rzeźba Umierającego gladiatora z Muzeum Kapitolińskiego „Wyobraża [...] ród słowiański dojrzały już do przyjęcia chrześcijaństwa", ibidem, s. 246.

${ }^{7}$ Szerzej na temat przeciwstawienia Słowiańszczyzny i Europy w pismach Mickiewicza pisze Monika Rudaś-Grodzka, por. tejże, Europejska przygoda Stowian w świetle Prelekcji paryskich Adama Mickiewicza. Stowiańszczyzna zniewolona, w: Romantycy i Europa. Marzenia, doświadczenia, propozycje. Red. M. Piwińska. Warszawa 2006.

${ }^{8}$ Antyteza słowiańsko-europejska ujawniła się także w wypowiedziach słowianofilów rosyjskich, tu jednak miała swoisty, inny od analizowanego przeze mnie charakter. Słowianofile ci (np. Iwan Aksakow, Iwan Kirejewski, Aleksiej Chomiakow) starali się nadać elementowi rodzimemu (nominalnie słowiańskiemu, faktycznie rosyjskiemu) walor sakralny, dyskredytując jednocześnie Europę niesłowiańską pod niemal każdym względem. 
szonej ojczyźnie przypisywały misję walki z tyranią (przede wszystkim rosyjską) oraz wyzwolenia zdegenerowanej duchowo i politycznie Europy ${ }^{9}$.

Horyzontalny, równoleżnikowy sposób definiowania Słowiańszczyzny w odniesieniu do zachodniej Europy i wschodniej Rosji dominował przez długie lata, dając Słowianom ograniczone możliwości wyjścia z impasu niepełnowartościowości. W omówionej perspektywie można było albo identyfikować się z mitem słowiańskim i godzić na wymazywanie z kulturalnej mapy Europy, albo kompensować sobie poczucie gorszości wizją moralnej wyższości nad materialistycznym, zsekularyzowanym Okcydentem i dziką Rosją. Oba wyjścia - należy podkreślić nie stanowiły przy tym żelaznej alternatywy; nader często to drugie wynikało z pierwszego.

Inną formułę myślenia o tej części Europy przyniosło dwudziestolecie międzywojenne. Idea zjednoczenia Słowian w wersji panslawistycznej, zakładającej hegemoniczną rolę Rosji, została wówczas zarzucona, ponieważ oznaczała wchłonięcie mniejszych narodów, które, dopiero co, uzyskały niepodległość, przez najpotężniejszego, ale nietypowego reprezentanta Słowiańszczyzny - kraj niechętny tradycji łacińskiej i antycznej, nadal kojarzony z Orientem oraz cywilizacją o walorach żeńskich ${ }^{10}$. Co ważniejsze jednak, horyzontalny, równoleżnikowy paradygmat, o którym była mowa, paradygmat oparty na opozycji Wschód - Zachód, uległ zmianie na paradygmat wertykalny, południkowy, umożliwiający stworzenie nowej wersji mitu słowiańskiego czy precyzyjniej: środkowoeuropejskiego, bo poszerzonego o narody ugrofińskie i romańskie, a w niektórych wariantach nawet o narody bałtyckie. Głównym punktem odniesienia w owym micie stały się nacje bałkańskie. Monika Bednarczuk i Monika Rudaś-Grodzka, tak komentują to zjawisko:

Rozczarowanie stanem narodu i państwa w latach trzydziestych XX wieku prowokuje spojrzenie na Południe jako kontrapunkt. [...] Południe staje się szansą na wyleczenie środka [Europy - J.W.] z mentalnego cierpienia. W licznych propozycjach kulturowopolitycznych ujawniają się nie zachodnioeuropejskie, ale 'jugosłowiańskie' albo 'bułgarskie' kompleksy ${ }^{11}$.

Owe "jugosłowiańskie” albo „bułgarskie” kompleksy nie były tak destrukcyjne, jak poczucie gorszości od Rosji i Zachodu, przeciwnie, łatwiej niż to ostatnie dawały się przekuć w źródło siły i wyjątkowości. Południe, choć przedstawiało sobą to, co godne prawdziwego podziwu i wielkiej zazdrości, mogło przecież dać impuls do wzmocnienia przedstawicieli środkowoeuropejskich nacji - w końcu pobratymców tak imponujących im mieszkańców Półwyspu Bałkańskiego.

${ }_{9}^{9}$ Por. M. Bobrownicka, Antyteza słowiańsko-europejska. Z problemów stereotypu, w: Kategoria Europy w kulturach stowiańskich. Red. T. Dąbek-Wirgowa, A. Z. Makowiecki. Warszawa 1992.

10 Por. W. Stiepanienko, "Kobiecość" i "męskość" w postrzeganiu kultury sasiadów. Przeł. A. Siciński. „Kultura i Społeczeństwo” 1991, nr 4, s. 77.

${ }^{11}$ M. Bednarczuk, M. Rudaś-Grodzka, Cierpienie przestrzeni środka. „Teksty Drugie” 2008, nr 4, s. 80. 
W trzeciej dekadzie ubiegłego wieku na gruncie polskim sympatie dla „braci z Południa" podzielali reprezentanci większości opcji politycznych, począwszy od nacjonalistów, skończywszy na lewicowcach, regionalistach i pacyfistach. Objawiły się one przede wszystkim w licznych i chętnie wówczas czytanych relacjach z wypraw, reportażach, felietonach i przewodnikach. W owej literaturze kreowano mit Południa: zachwycano się bałkańskimi krajobrazami oraz urodą, młodzieńczą witalnością i uzdolnieniami południowców.

W tym kraju [Jugosławii - J.W.] najlepiej nie zwracać na siebie uwagi. Ten kraj graniczy z Grecją, a ciała tych ludzi graniczą z greckim ideałem piękna. Ale jak wytłumaczyć zagadkę: dlaczego $\mathrm{w}$ pewnych stronach świata udają się same dorodne, źrałe, dostałe okazy gatunku Homo sapiens, a w innych przeważnie są już zdegenerowane? [...] Czemu my, na Północy, mamy nie tylko zaflegmione głosy, ale i zaflegmione dusze, chmurne i nieprzystępne, a oni, Słowianie z Południa, śpiewają nawet wtedy, gdy płaczą? ${ }^{12}$.

Tak pytał Józef Wittlin, ale zaraz - jak wielu innych twórców - doznawał pocieszenia na myśl, że na owej Północy nie tylko Polacy, ale również narody zachodnioeuropejskie cierpią na przypadłość wiecznego smutku i wyglądają ",jak senne upiory"13. Poza tym, słowiańskim Polakom było bliżej do ideału homo balcanicus niż zachodnim Europejczykom - ten fakt dodawał polskim literatom jeszcze większej otuchy, bo wskrzeszał ideę zjednoczenia nacji środkowoeuropejskich. I rzeczywiście: w latach trzydziestych zaczęto podkreślać wspólnotę kultury oraz tragicznej przeszłości środkowych Europejczyków, proponując różne sposoby odbudowania więzi łączącej Północ i Południe tej części kontynentu. Niektórzy akcentowali męski potencjał południowych Słowian, z którym powinni się połączyć mieszkańcy Północy. Inni nawiązywali do bałkańskiego podania o trzech braciach: Lechu, Czechu i Mechu, którzy niegdyś wyruszyli na Północ, do krainy przodków, a teraz powrócą do oczekującej ich na Południu siostry Tugi ${ }^{14}$. I jedni, i drudzy zgodnie twierdzili wszakże, że środkowi Europejczycy powinni wzorować się na południowcach po to, aby uśmierzyć swoje bolączki i uzdrowić kompleksy. O tym, jak popularne były owe teorie, wiele mówi prześmiewcza, nie pozbawiona ironii wypowiedź Adolfa Nowaczyńskiego:

Na Zachód tedy pod żadnym pozorem w tym roku. W zmian za to na Jug, na Południe! I to dobrze by było demonstracyjnie i masowo. To będzie najmądrzejsze [...] wylegity-

12 J. Wittlin, Etapy i nowe etapy, w: idem, Orfeusz w piekle XX wieku. Posłowie J. Zieliński. Kraków 2000, s. 242.

${ }^{13}$ Ibidem. Interesujące omówienie części Etapów pt. Z walizy jugostowiańskiej zawiera artykuł Rafała Szczerbakiewicza Bałkańska "sól ziemi”. Reportażowa miniatura Józefa Wittlina, w: Południowa Stowiańszczyzna w literaturze polskiej XIX i XX wieku. Red. K. Stępnik, M. Gabryś. Lublin 2010.

${ }_{14}$ Oba te warianty obszernie omawiają M. Bednarczuk, M. Rudaś-Grodzka w artykule Cierpienie przestrzeni środka, op. cit., s. 85-87. 
mowanie się naszą słowińską solidarnością. Krociowy exodus Sarmatów nad Jadrań, znaczy się nad Adriatyk. Niech tam idą pociągi za pociągami. [...] I niech z tych pociągów wysypią się tysiące tych, co spragnieni Słońca, Zdrowia i Piękna. I niech tam począwszy od maja zacznie brzmieć polska mowa wszędzie-wszędzie [...] Niech bladzi ludzie z Północy, z Judosławii, zapełnią całe Przymurze piaszczyste Jugosławii i niech tam nabiorą rumieńców, zdrowia, krzepy, optymizmu i joie de vivre ${ }^{15}$.

W nowym dwudziestoleciu ${ }^{16}$, to jest okresie po 1989 roku, dziś wydłużonym już do dwudziestu trzech lat, mit Europy Środkowej nie zniknął, przeciwnie, podsycony słynną dyskusją zainicjowaną przez Milana Kunderę na łamach "Zeszytów Literackich"17 stał się nawet silniejszy niż w latach 1918-1939. Co ciekawe, niektóre jego warianty nadal realizują paradygmat wertykalny, południkowy, i opierają się na micie Południa18. W rzeczywistości polskiej na tę tendencję wskazuje popularność utworów bałkańskich pisarzy (na przykład Serba Danila Kiša, Albańczyka Fatosa Kongoli, pochodzącego z Bośni i Hercegowiny Nenada Veličkovicia oraz twórców chorwackich: Miljenka Jergovicia i Dubravki Ugrešić), a do pewnego stopnia także literatury faktu dotyczącej konfliktów na Bałkanach (pióra reportażystów polskich, choćby Dawida Warszawskiego, Tadeusza Olszańskiego czy Jana Piekły, oraz zagranicznych, na przykład Roberta D. Kaplana). Przede wszystkim jednak wspomniana tendencja daje o sobie znać w dorobku czołowego polskiego eksploratora środkowoeuropejskich tematów, Andrzeja Stasiuka.

Mit Południa jako podstawa mitu Europy Środkowej, obecny w twórczości tego pisarza, zdradza pewne podobieństwo do wariantu, który rozwinął się w literaturze polskiej w latach trzydziestych; podobieństwo to jako nie-tożsamość zakłada jednak istnienie ważnych różnic. Pierwsza z nich ma naturę geograficzną i sprowadza się do tego, że inne regiony składały się na Południe bliskie twórcom międzywojennym, a inne składają się na Południe Stasiuka. Ci pierwsi, poza Grecją, najbardziej interesowali się ziemiami jugosłowiańskimi: Dalmacją, Chorwacją i Serbią, poza dyskursem bałkańskim pozostawiali natomiast Bośnię i Hercegowinę, a zwłaszcza Sarajewo - jak sądzili - oazę „turecczyzny” oraz źródło konfliktów religijnych i społecznych ${ }^{19}$. Stasiuk natomiast w ogóle nie przekracza granicy Gre-

\footnotetext{
15 A. Nowaczyński, Uroda S.H.S.. „Prosto z Mostu” 1937, nr 15-16, s. 7.

16 Por. Nowe dwudziestolecie (1989-2009): rozpoznania, hierarchie, perspektywy. Red. H. Gosk. Wyd. Elipsa, Warszawa 2010.

${ }_{17}$ Por. M. Kundera, Zachód porwany albo tragedia Europy Środkowej. Przeł. M. L. „Zeszyty Literackie" 1984, z. 5 .

${ }^{18}$ Odrębny temat stanowią kreacje mitu Północy, również mieszczące się w ramach paradygmatu wertykalnego, południkowego, obecne np. w twórczości Mariusza Wilka. Temat ów jedynie odnotowuję, ponieważ ich relacje $\mathrm{z}$ mitem środkowoeuropejskim mają zupełnie inny charakter niż związki mitu Południa z mitem Europy Środkowej.

${ }^{19} \mathrm{~Np}$. Z. Starowieyska-Morstinowa uważała, że w Sarajewie „[...] jesteśmy u dna różnic dzielących ludzi najbardziej zasadniczo", por. Eadem, Kamień i woda. Wrażenia z Jugosławii. Poznań 1936, s. 106.
} 
cji - ta jest dla niego nieciekawą "historyczną skamieliną"20 - jak ognia unika kurortów, najchętniej włóczy się po prowincjonalnych wsiach i miasteczkach, a za najbardziej charakterystyczne rewiry Południa uznaje właśnie Bośnię i Hercegowinę, Rumunię (nie bez powodu jedna z jego książek nosi tytuł Jadąc do Babadag) oraz Albanię ${ }^{21}$. Druga różnica wynika stąd, że literaci międzywojenni, jakkolwiek pisali o młodych tworach politycznych, dalekich od pełnej stabilizacji, mieli skłonność do ich bezkrytycznego idealizowania, jako konglomeratu, „najpiękniejszych pierwiastków przejętych z krwi Rzymian, Greków i Włochów"22. Stasiuk tymczasem wie, że opowiada o europejskim jądrze ciemności i, choć na swój sposób, również idealizuje Południe, nie zapomina o nieodległych w czasie, rozdzierających je konfliktach. Obie różnice decydują o tym, że elementy strukturalne mitu Południa w twórczości autora Fado różnią się od tych, które można zidentyfikować $\mathrm{w}$ polskiej literaturze i publicystyce lat trzydziestych. Wizję doskonałego krajobrazu oraz cielesno-duchowej harmonii uosabianej przez południowców zastępują tu: motywy cekańskie, idea cywilizacji naddunajskiej, specyficznie przekształcony topos "poezji ruin” i kreacja Cyganów na bohaterów kulturowych.

Zacznijmy od motywów cekańskich. Dla Stasiuka Południe zaczyna się tam, gdzie leżały Austro-Węgry, a zwłaszcza takie ziemie cesarstwa, jak Transylwania, Banat, Bośnia i Hercegowina. Pisarz, zanim wybiera się do Albanii, Bułgarii i Macedonii 23 , długo krąży po byłym obszarze Cekanii24, a następnie nie może się ustrzec przed ekstrapolowaniem swoich obserwacji na realia krajów, które nie wchodziły w jej skład. Razi to o tyle mniej, o ile autor Fado utożsamia AustroWęgry nie z historią, a z kulturą. Dla niego Cekania to bowiem wcielenie fikcyjności, nierzeczywistości i nieokreśloności, nietrwałości i marginalizacji dziejów, autoparodii i czynienia ze słabości siły. Ale nie tylko, bo także kultu konkretu, sprzeciwu wobec rewolucji, pochwały powolnych zmian i władzy, która nie czyni

20 Por. A. Stasiuk, Jadąc do Babadag. Wołowiec 2004, s. 106. Nieco łatwiej zrozumieć ten punkt widzenia, gdy się pamięta, że pisarz wyznaje zasadę, iż: „Przeszłość im starsza, tym jest gorsza”, ibidem, s. 187.

${ }^{21}$ Stasiuk wyłącza z dyskursu bałkańskiego Słowenię, a poniekąd także Chorwację. Zgadza się $\mathrm{z}$ tezą, ze z historyczno-kulturowego punktu widzenia, a w przypadku Słowenii także z geograficznego punku widzenia, kraje te są bliższe Zachodowi niż Bałkanom. Por. zwłaszcza ibidem, esej pt. Kraj, w którym zaczęta się wojna.

22 H. Siennicka, Uroda Jugostawii. Warszawa 1936, s. 293.

23 Wbrew pewnym aktualnym zachodnioeuropejskim aspiracjom Macedonii Stasiuk uznaje ten kraj za typowo bałkański. Por. zwłaszcza A. Stasiuk, Dziennik pisany później. Fotografie D. Pawelec. Wołowiec 2010, esej 2.

24 Pojęcie "Cekania” pochodzi od nazwy „cesarsko-królewska monarchia” lub „c.k. monarchia” (w mowie" ceka monarchia) stosowanej na określenie Austro-Węgier. Określenie ","cesarsko-królewski" pochodzi od tytułu władcy Austro-Węgier, który był cesarzem Austrii i królem Węgier jednocześnie. 
różnicy „między Serbem a Słowakiem, Polakiem a Rumunem”25. Krótko mówiąc, Cekania to uosobienie austro-węgierskiego dekadentyzmu i paternalizmu, który $\mathrm{z}$ mitu przekształcił się w stereotyp.

[...] zaczynam rozumieć, czym sto lat temu było Cesarstwo. Istniało jako przestrzeń, w której każda ucieczka wydawała się możliwa. [...] tamta Europa przypominała prowincjuszkę zatopioną $w$ marzeniach o metropolii. Prawdziwe życie miało toczyć się nie tyle gdzie indziej, co kiedy indziej, miało toczyć się w przyszłości. [...] Jej rojenia nie dotyczyły dalekich krain, chociaż i w jej obrębie znalazłyby się jeszcze miejsca, gdzie wciąż w dobrej kondycji przechadzały się wilkołaki i podfruwały gryfy. [...] Właśnie ona jako coś nieskończenie plastycznego i rozciągliwego, mogła pomieścić wszystkie zmaterializowane marzenia i wymyślone kształty ${ }^{26}$.

Tak pisze Stasiuk o niegdysiejszych ziemiach Habsburgów, a siła jego narracji bierze się stąd, że doskonale wie, iż wdaje się w grę stereotypów. Świadczy o tym fakt, że ujawnia konwencjonalność swojej opowieści, balansuje na pograniczu gatunków i stylów wypowiedzi, zdradza źródła nawiązań i cytatów, a nade wszystko nie boi się oczywistych toposów i szablonowych obrazów. Nawet tak szablonowych, jak ten, przedstawiający toast za zdrowie Franciszka Józefa, wzniesiony 18 sierpnia, a więc w dniu narodzin Najjaśniejszego Pana, pod sklepem w Gönc, z przygodnie napotkanym Węgrem - toast okraszony słowami:

zawsze byłem za królami i cesarzami, [...] w tym marnym czasie szczególnie mi ich brakuje, ponieważ demokracja nie zaspokaja pragnień estetycznych ani mitologicznych, i człowiek czuje się nieco osamotniony, gdy musi oglądać w telewizji swoich prezydentów wybranych w powszechnych wyborach ${ }^{27}$.

Dzięki takim deziluzyjnym zabiegom Stasiuk rozbraja stereotyp i z wirtualnego świata Austro-Węgier powraca do realności obszarów, które tworzyły Cesarstwo-Królestwo. Na dowód - jeszcze jeden cytat: „Nuda i rozkład Kukanii, jakie opisują literaci, stanowiły w znacznej części wytwór ich umysłów" - czytamy w Dzienniku okrętowym, a zaraz potem: „Rzeczywistość w tej dziedzinie już niedługo miała przerosnąć ich usiłowania"28. Przez trywializację autor uwzniośla jednak ową realność i, jak się rzekło, rozciąga jej cechy na cały rejon między Węgrami a Grecją, refrenicznie powtarzając wzmianki o niezauważalności granic oraz uderzającym podobieństwie krajobrazów i doświadczenia ludzi w tej części kontynentu29.

\footnotetext{
${ }^{25}$ Idem, Dziennik okrętowy, w: J. Andruchowycz, A. Stasiuk, Moja Europa. Dwa Eseje o Europie zwanej Środkowa. Wołowiec 2001, s. 125.

${ }^{26}$ Ibidem, s. 124-125.

27 Ibidem, s. 126.

28 Oba cytaty pochodzą z: ibidem, s. 124.

29 Por. np.: „Słowackie nazwy niepostrzeżenie zmieniłyby się $\mathrm{w}$ węgierskie, potem $\mathrm{w}$ rumuńskie, w serbskie, macedońskie i w końcu zapewne w albańskie - jeśli przyjąć, że droga wiodłaby mniej więcej opłotkami dwudziestego pierwszego stopnia długości geograficznej wschodniej", Idem, Jadąc
} 
W rezultacie tworzy swoją wersję mitu Europy Środkowej, która wzniesiona jest na gruzach mitu Cekanii, a której centrum znajduje się na rozległym obszarze na południe od Budapesztu. W mitograficznym stylu przyznaje się nawet do wiary, że po odejściu Najjaśniejszego Pana to tam właśnie, na Południu, objawi się ,jakieś historyczne albo geopolityczne satori" 30 .

Drugi składnik mitu Południa w twórczości Stasiuka wynika z dystansowania się od mitu śródziemnomorskiego oraz przemieszczania go w stronę Morza Czarnego i Dunaju. Konsekwentnie w stosunku do motywów cekańskich pisarz kreuje wizję Europy Środkowej jako cywilizacji naddunajskiej; znów czyni to jednak na swój sposób. Po pierwsze, dużą wagę przywiązuje do tego, że w przypadku Dunaju - jedynej w Europie większej rzeki płynącej z zachodu na wschód - kilometry liczy się w stronę przeciwną niż kierunek prądu, to znaczy w górę cieku: oto mitycznym źródłem Dunaju jest dla autora Fado deltowe ujście, a dokładnie latarnia morska w Sulinie, o tyle trafnie wybrana, że stanowi również oficjalny punkt "zero" "Ojca Rzek". To tłumaczy, dlaczego Stasiuk nie jeździ w góry Schwarzwaldu, z których Dunaj wypływa, tylko do Babadag, oraz z jakiego powodu dowartościowuje Rumunię jako jeden z najważniejszych krajów tej części kontynentu. Tam przecież znajdują się rzeczne ramię i deltowa dłoń - „Place odnóg, ścięgna kanałów, paznokcie piaszczystych plaż na wybrzeżu [...] pokryte zieloną skórą bagien" 31 - czyli prawa ręka Europy Środkowej. Tam też udręczeni środkowi Europejczycy zostają ze "swoją klątwą i histerią" 32 , ale jednocześnie nadzieją, że te skończą się kiedyś, tak, jak kończą się rzeka i ziemia, które przepadają w morzu. Po drugie, Stasiuk zdecydowanie bardziej interesuje się południowym niż północnym dorzeczem Dunaju, nie ukrywając, że ów wybór, choć arbitralny, jest jedynym, na jaki go stać. Na południe „zapuszcza się moja wyobraźnia, śmiertelnie znużona zachodem, wschodem i północą, w których długim cieniu spędziłem większą część życia"33 - tłumaczy, a gdzie indziej dokładnie określa, w jaki rejon europejskiego zlewiska rzek chce podróżować: „Na Południe. Prawie zawsze na południe. [...] Na koniec kontynentu, na skraj lądu, na brzeg wód, żeby patrzeć, jak cię ściga cień. Na Bałkany"34. Jest to powód, dla którego takie państwa, jak Rumunia, Bułgaria, Mołdawia i Serbia, a nawet Bośnia i Hercegowina (połączone z Dunajem jedynie dopływem Sawy) są dla Stasiuka paradoksalnie bardziej naddunajskie niż Austria i Niemcy. W jego optyce Dunaj stanowi nie tyle konkretny

do Babadag, op. cit., s. 241. Lub: „Do Wołomina jest trzydzieści kilometrów [...]. Zjeżdżam na bok i kątem oka łapię prostakowate twarze chłopskich synów i wnuków, którzy nareszcie mają do woli sterydów i mięsa. Przypominają chłopaków z Bajram Curri, z Kragujevaca, z Prisztiny", idem, Dziennik pisany później, op. cit., s. 152.

\footnotetext{
${ }^{30}$ Idem, Dziennik okrętowy, op. cit., s. 126-127.

${ }^{31}$ Idem, Jadac do Babadag, op. cit., s. 187.

32 Ibidem.

${ }^{33}$ Idem, Dziennik okrętowy, op. cit., s. 87.

34 dem, Dziennik pisany później, op. cit., s. 131-132.
} 
obiekt geograficzny, ile symbol metafizyczny środkowoeuropejskiej cywilizacji, która nigdzie nie daje o sobie znać z taką intensywnością, jak na Południu. Korytem tej właśnie rzeki, a nie na przykład Wisły35, wypływa z ciała Europy Środkowej „zielonkawa krew". Wbrew utartej topice ruch ten nie powoduje jednak utraty sił witalnych ${ }^{36}$, przeciwnie, spustoszonym ziemiom nadaje pewną transcendencję i stygmat pozawyznaniowej religijności.

Trzecim elementem omawianego mitu czyni Stasiuk specyficzną wizję niszczenia tworów cywilizacji i kultury. W ujęciu pisarza owo niszczenie stanowi cechę dystynktywną Europy Środkowej, pełnej śladów i ruin.

[...] te wszystkie miejsca i rzeczy to jest rozpad, rozpierducha, ledwo kamień na kamieniu albo resztki dawnej świetności [...]. - czytamy w Jadac do Babadag - To jest specjalność mojej części świata, ten nieustanny zanik pomieszany pół na pół ze wzrostem, ten cwany niedorozwój, który każe wszystko brać na przeczekanie, ta niechęć do eksperymentów na własnym organizmie, to wieczne na pół gwizdka, które pozwala wyskoczyć na brzeg strumienia czasu i akcję zastąpić kontemplacją ${ }^{37}$.

Zdaniem autora środkowoeuropejski pejzaż najpełniej objawia swoją ruinę na Południu: to tam, a zwłaszcza w Rumunii i Albanii, pisarz widzi „ostateczną dekadencję industrialu" 38 - domy $w$ stanie rozsypki, hałdy śmieci, zrudziałe konstrukcje, wypatroszone maszyny oraz plątaniny drutów i szyn kolejnych prowadzących do nikąd. Dlatego twierdzi, że wszyscy powinni pojechać na Bałkany, bo Południe to podświadomość naszego kontynentu: „europejskie id, [...] lęk, który nawiedza nocą śpiący Paryż, Londyn i Frankfurt nad Menem. [...] ciemna studnia, w głąb której powinni zerknąć ci, którym się wydaje, że bieg rzeczy został ustalony raz na zawsze" 39 . Owa "filozofia ruiny", jako dialektyki rozpadu i budowy, nasuwa skojarzenie z koncepcją Waltera Benjamina. Niemiecki filozof zaproponował melancholiczną interpretację baroku jako kultury, która rozwijając gatunek dramatu tragicznego, ujawniła, że zarówno natura, jak i ludzkie dzieła to obszary beznadziejności i totalnego zniszczenia. „Pomniki i ruiny [...] są domem saturnicznych bestii" - przekonywał autor Pasaży ${ }^{40}$. Podobnie Stasiuk: w jego ujęciu rozpadanie się wytworów człowieka przed ich ostatecznym ukończeniem powoduje "środkowoeuropejski spleen”, a zwłaszcza „bezmierną melancholię" Południa41.

35 Por. idem, Dziennik okrętowy, op. cit., s.78-79.

36 Por. „Wyobrażałem sobie, jak z ciała kontynentu wypływa zielonkawa krew, lecz życie nie zamiera, i tak jest od tysiącleci", idem, Jadąc do Babadag, op. cit., s. 200.

37 Ibidem, s. 226.

38 Por. ibidem, s. 83.

39 Ibidem, s. 119.

${ }^{40}$ W. Benjamin, Ursprung des deutschen Trauerspiels. Berlin 1928. Korzystam z wersji angielskojęzycznej: The Origin of German Tragic Drama. Przeł. J. Osborn, wstęp G. Steiner. Londyn 2003, s. 179.

${ }^{41}$ Oba cytaty pochodzą z: A. Stasiuk, Tekturowy samolot. Wołowiec 2002, s. 66. Por. idem, Fado. Wołowiec 2006, s. 49. 
Różnica polega jednak na tym, że autor Fado, w przeciwieństwie do Benjamina, omija sensotwórcze możliwości lektury ruin i zamiast hermeneutyki śladu uprawia jego celebrację jako faktu. Powtarza więc topos „poezji ruin” z melancholiczną zadumą, ale bez refleksji historiozoficznej. Tę ostatnią zastępuje pochwałą pierwotnej natury, ona bowiem zajmuje miejsce przedmiotów i budowli, które ulegając atrofii, powracają do swoich elementarnych postaci, a następnie do wnętrza ziemi. I znów najdoskonalej ów proces uwidacznia się na Południu: "Jechaliśmy w stronę Sarajewa" - pisze na przykład Stasiuk - „Ten kraj był piękny urodą dawno wymarłego zwierzęcia." Wyglądał, jakby rządziła tu tylko geologia"42. Koncept rozpadu rzeczy i ich substancjalnej przemiany, choć nie podszyty historiozofią, ma $\mathrm{w}$ tego typu fragmentach uzasadnienie niemal soteriologiczne, pobrzmiewające językiem gnozy. Zbawienie, jeśli w ogóle nadejdzie, dokona się przez reinkarnację materii - sugeruje pisarz - a zacznie się na Południu, bo bałkański pejzaż jest najbliższy ideałowi ${ }^{43}$, to znaczy wieczności, $z$ której wyodrębniły się i do której powrócą i czas, i przestrzeń.

Uwrażliwienie Stasiuka na ruiny zyskuje potwierdzenie w czwartym elemencie mitu Południa, to jest kreacji Cyganów na bohaterów kulturowych Europy Środkowej. „Zjawiają się wszędzie tam, gdzie się wybiorę. Chwilami podejrzewam, że moja Europa pokrywa się miejscami, gdzie są widoczni, gdzie nie poddali się prawu mimikry czy też asymilacji" 44 - powiada autor Fado o przedstawicielach tej grupy etnicznej. Wiąże ich przy tym z dwoma kręgami sensów. Po pierwsze, przypisuje im rolę, jaką w micie Cekanii odgrywali Żydzi. Czyni to wprawdzie kosztem pewnych przemilczeń oraz podsuwania czytelnikowi presupozycji związanych z dyskryminacją Romów po ekscesy rasistowskie włącznie, ich eksterminacją $\mathrm{w}$ obozach zagłady oraz zmuszaniem do asymilacji $\mathrm{w}$ państwach komunistycznych. Uzyskuje jednak bardzo przekonujący efekt, a mianowicie wizerunek Cyganów jako współczesnych Wiecznych Tułaczy, włóczęgów europejskiej przestrzeni środka i wiejskich flâneur'ów. Po drugie - i ten krąg sensów jest bardziej interesujący w perspektywie moich rozważań - w różnoraki sposób łączy Romów z Południem. Przede wszystkim wywodzi reprezentantów tej nacji z najdalszych zakątków Półwyspu Bałkańskiego: „uświadomiłem sobie, że nie na darmo moje spojrzenie nocą opiera się o Peloponez. To właśnie tam Europa pierwszy raz dostrzegła i zapamiętała obecność swoich ostatnich nomadów" 45 . Poza tym kreuje ich na królów życia poza polityką i granicami państwowymi, na wirtuozów rozpadu oraz geniuszy przypadkowości i nietrwałości istnienia.

[...] dokądkolwiek się wybiorę, - pisze - zaraz rozglądam się za nimi, za tą żywą obrazą cywilizacji śródziemnomorskiej oraz chrześcijańskiej, za tym ludem bez ziemi, który

\footnotetext{
42 Idem, Dziennik pisany później, op. cit., s. 82.

43 Por. ibidem, s. 35.

${ }^{44}$ Idem, Dziennik okrętowy, op. cit., s. 129.

${ }^{45}$ Ibidem, s. 127
} 
nawet jak już coś zbuduje, to tak, jakby miał zaraz to porzucić, podpalić dla zabawy albo z rozpaczy i przenieść swoje ruchome państwo gdzieś dalej, gdzie biała europejska hołota dyszy mniejszą nienawiścią ${ }^{46}$.

W rezultacie zastosowania takich metafor Stasiuk tworzy obraz Cyganów jako ludzi żyjących „poza historią, [...] w czystym czasie i przestrzeni” 47 . Zgodnie z wizją pisarza mają oni specjalny rodzaj wyczucia metafizycznego, które pozwala im przeniknąć tajemnicę substancjalnej przemiany materii - jej ciążenia ku nicości i wieczności zarazem. Dlatego są predestynowani do życia właśnie na Południu Stasiuk powiada: $\mathrm{w}$ „,krainie śmierci” 48 - i uczestniczenia w jego przechodzeniu od form architektonicznych do geologicznych, a następnie takich, które przeczą idei kształtu i obnażają nagie kości ziemi.

Na koniec warto się zastanowić, na ile propozycja oparcia mitu Europy Środkowej na micie Południa, zawarta w tekstach Stasiuka, jest oryginalna i twórcza. Zrazu wydawać się może, że tylko w ograniczonym stopniu. Omówione elementy mitu Południa reaktywują $u$ tego pisarza takie wątki dyskursu środkowoeuropejskiego, które są rozpoznawalne, by nie rzec: wyeksploatowane. Wskazując na przeszłość austro-węgierską, autor Fado powtarza ideę środkowoeuropejskiej wielokulturowości i twórczej amorficzności. Stawiając na Dunaj jako metafizyczny symbol oraz topikę pochłanianych przez naturę ruin, przypomina kompensacyjną myśl, że mieszkańcy tej części kontynentu są w szczególny sposób uduchowieni, a ich doświadczenie stanowi memento dla innych krajów, które czeka ten sam los. Wybierając Cyganów, tworzy zaś swoją wersję stereotypu młodszej, bardziej autentycznej, a zarazem egzotycznej dla Zachodu Europy, która interioryzuje obcość i różnice. Co więcej, owe elementy w różnych konfiguracjach można zlokalizować w dorobku innych współczesnych twórców. Cyganie fascynowali Jerzego Ficowskiego $^{49}$ i wciąż fascynują Emira Kusturicę ${ }^{50}$. Środkowoeuropejskie życie wśród ruin pociąga między innymi Jachyma Topola ${ }^{51}$ i Jurija Andruchowycza, a Dunaj i Austro-Węgry - Andruchowycza ${ }^{52}$ i Claudia Magrisa ${ }^{53}$.

Oryginalność oraz twórczy potencjał propozycji autora Fado nie biorą się zatem z samego wpisania środkowoeuropejskiej narracji w paradygmat wertykalny, południkowy, ani nawet z zaakcentowania określonych wątków tej narracji. Wspo-

${ }^{46}$ Idem, Jadac do Babadag, op. cit., s. 215-216.

47 Idem, Dziennik okrętowy, op. cit., s. 130.

48 Por. Idem, Dziennik pisany później, op. cit., s. 132.

49 Por. zwłaszcza J. Ficowski, Cyganie w Polsce: dzieje i obyczaje. Warszawa 1989.

50 Por. zwłaszcza Czas Cyganów (1988), Czarny kot, biały kot (1998), reż. Emir Kusturica.

51 Por. zwłaszcza J. Topol, Supermarket bohaterów radzieckich. Przeł. L. Engelking. Wołowiec 2005.

52 Por. zwłaszcza J. Andruchowycz, Środkowoeuropejskie rewizje. Przeł. L. Stefanowska, w: J. Andruchowycz, A. Stasiuk, Moja Europa, op. cit., Idem, Ostatnie terytorium. Przeł. O. Hnatiuk, K. Kotyńska, L. Stefanowska. Wołowiec 2002.

53 Por. zwłaszcza C. Magris, Dunaj. Przeł. J. Ugniewska, A. Osmólska-Mętak. Warszawa 2004. 
mnianych oryginalności i twórczego potencjału można natomiast upatrywać w dwóch innych prawidłowościach opowieści Stasiuka. Po pierwsze, wiążąc ze sobą motywy cekańskie, ideę cywilizacji naddunajskiej, specyficznie przekształconą topikę "poezji ruin” oraz kreację Cyganów na bohaterów kulturowych, pisarz podejmuje mitotwórczą działalność bardzo świadomie. W metatekstowej warstwie swoich utworów wielokrotnie formułuje uwagi, które o tym świadczą:

Tak sobie myślałem o mojej Europie - powiada na przykład - [...] o ostatnim przyzwoitym micie czy też złudzeniu przykładanym do rany i otarcia bezdomności $\mathrm{w}$ tym coraz bardziej bezprizornym świecie. Oczywiście były to myśli pięknoducha, niemniej oddawałem się im z wielką przyjemnością gdzieś między Nagykálló i Mátészalka pod purpurowym niebem zachodu ${ }^{54}$.

W innym miejscu pisze na temat samego Południa, stosując wymowną litotę:

[...] nie czuję się najgorzej gdzieś między Belgradem a Tiraną, chociaż moja wiedza o tych krajach jest niedoskonała, fragmentaryczna, ale może właśnie dzięki temu to wszystko wydaje mi się dość pociągające ${ }^{55}$.

Owo niemal programowe uleganie „środkowoeuropejskiej chorobie" - bo tak nazywa Stasiuk tworzenie bałkańskiej utopii - odróżnia autora Fado od pisarzy lat trzydziestych, którzy - jak wspominałam - przedstawiali Południe dość bezkrytycznie, z niewielką lub zerową dozą mitotwórczej świadomości.

Po drugie, dowartościowując Południe jako fundament mitu Europy Środkowej, Stasiuk dokonuje - znów bardzo świadomie - określonego wyboru ideologicznego. Ten wybór odróżnia autora Fado od niektórych współczesnych pisarzy, którzy wykorzystują wybrane elementy mitu Południa, lecz wkomponowują je w inne całości znaczeniowe, a w związku z tym nie tworzą, jak Stasiuk, omawianego mitu. Weźmy na przykład Andruchowycza. Topika "poezji ruin” służy u niego kreacji nowej środkowoeuropejskiej tożsamości jako wzorcowo postmodernistycznej56, a motywy cekańskie i odwołanie do idei cywilizacji naddunajskiej - powiązaniu Europy Środkowej z Zachodem ${ }^{57}$. Podobnie jest u Magrisa. Ten

\footnotetext{
${ }^{54}$ A. Stasiuk, Jadac do Babadag, op. cit., s. 78.

55 Idem, Dziennik pisany później, op. cit., s. 95.

56 Por.: „, [...] właśnie tu, na tym terytorium [Europy Środkowej - J.W.] dostrzegam pewne oznaki tego, co sam uważam za "post-modernistyczne”, to znaczy przede wszystkim "po-modernistyczne”, czyli coś, co przyszło po modernizmie z jego zasadniczym pragnieniem nowoczesności, nowości jako odpowiednika czasu [...] [:] pustka, wielkie wyczerpanie z nieskończenie otwartym potencjałem, ogromna wiele obiecująca pustka", J. Andruchowycz, Ostatnie terytorium, op. cit., s. 137-138.

57 Por.: „Za Dunajem leży Ameryka, czyli przyszłość, za Dunajem leży wszystko, co z czasem ma się spełnić (albo nie spełnić). W rzeczywistości Dunaj jest Oceanem, on przyciąga. Jego bliska obecność oznacza bardzo wiele: czas, wieczność, historię, mitologię, nas samych", tegoż, Środkowoeuropejskie rewizje, op. cit., s. 24.
} 
okcydentalista, spadkobierca rzymskiej i miejskiej tradycji, wpisuje wyobrażenie Ojca Rzek w mit śródziemnomorski i podkreśla, że w modrych falach Dunaju połyskuje złoto Renu ${ }^{58}$. Zupełnie inaczej jest w przypadku Stasiuka. Sama jego definicja egzystencji w Europie Środkowej brzmi jak kalambur na temat przekraczania opozycji Wschód - Zachód: „Żyć między Wschodem, który nigdy nie istniał, a Zachodem, który istniał zanadto" 59 . Owa definicja wskazuje na konieczność funkcjonowania między pustką po komunizmie ${ }^{60}$ a odpadami zachodnioeuropejskiej cywilizacji, które sprzedaje się na środkowoeuropejskich bazarach. Jedyne wyjście z impasu tej alternatywy wiedzie, zdaniem pisarza, na Południe.

Ponieważ jestem kundlem, ponieważ jestem z innych stron, ponieważ nie chcę niczego udawać. Ponieważ jestem mieszańcem Wschodu i Zachodu. Dlatego wybieram te heretyckie kraje. Tych odszczepieńców, którzy od czasu do czasu wabią światowe telewizje zapachem $\mathrm{krwi}^{61}$ -

- tłumaczy autor Fado, po czym uzupełnia: jeżdżę na Południe, bo czuję, że „na północy, na zachodzie nic dla mnie nie ma, a wschód ze swoją pograniczną bandyterką [...] [jest - J.W.] wyzwaniem ponad siły"62. Jak zatem bałkanofile lat trzydziestych, rozczarowani kształtem Polski kilkanaście lat po odzyskaniu niepodległości, tak Stasiuk, nieukontentowany sytuacją we własnym "biednym”, "opuszczonym" kraju63 mniej więcej dekadę po przełomie politycznym, zwraca się na Południe; w ten sposób kształtuje swą środkowoeuropejską opowieść nie tylko pod względem geopoetologicznym, ale również politycznym. Pisarz nie ukrywa, że podróżuje na Bałkany po to, „żeby tam medytować na słowiańskim losem” 64 , to znaczy znaleźć formułę wyjątkowości Europy Środkowej, a zwłaszcza Polski, i odróżnić te byty geograficzno-polityczne od Wschodu i od Zachodu. „Stamtąd lepiej widać, jak ojczyzna stoi w rozkroku i nie może się zdecydować. Z tych krain

58 Por.: „Czy Dunaj oddala się coraz bardziej od Renu, czy też jego przeznaczeniem jest uchodzić za emisariusza tych germańskich wód na Wschodzie? [...] Literaci skłonni są widzieć jedynie Dunaj wielonarodowy, historycy zaś liczą się również z niemieckością naddunajskiej Austrii, ze złotem Renu połyskująco często w modrym Dunaju", C. Magris, Kwestia rynien. Przeł. J. Ugniewska, w: idem, op. cit., s. 25.

59 A. Stasiuk, Dziennik okrętowy, op. cit., s. 136.

${ }^{60}$ Tezę Stasiuka o nieistnieniu Wschodu można również interpretować w kontekście teorii Edwarda W. Saida. Według badacza Zachód tworzył reprezentacje Wschodu w związku ze swoimi imperialistycznymi ambicjami politycznymi, dlatego Wschód „był prawie wyłącznie europejskim wynalazkiem", por. E.W. Said, Orientalizm. Przeł. M. Wyrwas-Wiśniewska. Poznań 2005. Zacytowana fraza pochodzi ze strony 29.

${ }^{61}$ A. Stasiuk, Dziennik pisany później, op. cit., s. 121-122.

62 Ibidem, s. 132.

63 To najczęściej stosowane do opisania Polski epitety w Dzienniku pisanym później, por. ibidem, s. 131 i n.

64 Ibidem, s. 133. 
śmierci. Z tych nowych tworów politycznych, które powstając, pogrążały się w zagładzie”65 - przekonuje i dopowiada: "Trzeba [...] wyjechać. [...] Dopiero wtedy widać, co tu jest. Z Theth na drogę 816. Z Ułan Ude na drogę 897. Z tych stron ubogie ludy nadejdą po swoją część bogactw. Tak jak my nadchodzimy"66. Choć inaczej konstruuje mit Południa niż pisarze lat trzydziestych, Stasiuk podobnie jak oni myśli, że ów mit to najlepsze, co można dać Europie Środkowej. Dzięki niemu Europa Środkowa przestanie być - to koncept z Dziennika okrętowego - lędźwiami starego, lepszego świata ${ }^{67}$. Zamiast tego rozpozna wyjątkowość i integralność własnego ciała, którego „Głowa [leży - J.W] wśród zielonych wzgórz Zemplén, serce gdzieś w Siedmiogrodzie, prawa dłoń w Czarnohorze, lewa w Białej Spiskiej, wzrok na Bukowinie, węch w Răşinari, [a - J.W] myśli może gdzieś tutaj..."68.

65 Ibidem, s. 137.

66 Ibidem, s. 154.

67 Por.: „Tak, Europo, twoje serce bije gdzieś między Dijon a Paryżem, a twoja piękna głowa to Iberia w błękitnej pościeli wód. Twój nienasycony brzuch to Niemcy. A ja? To znaczy my? Bylibyśmy twoimi lędźwiami?", idem, Dziennik okrętowy, op. cit., s. 111.

68 Idem, Jadac do Babadag, op. cit., s. 7. 


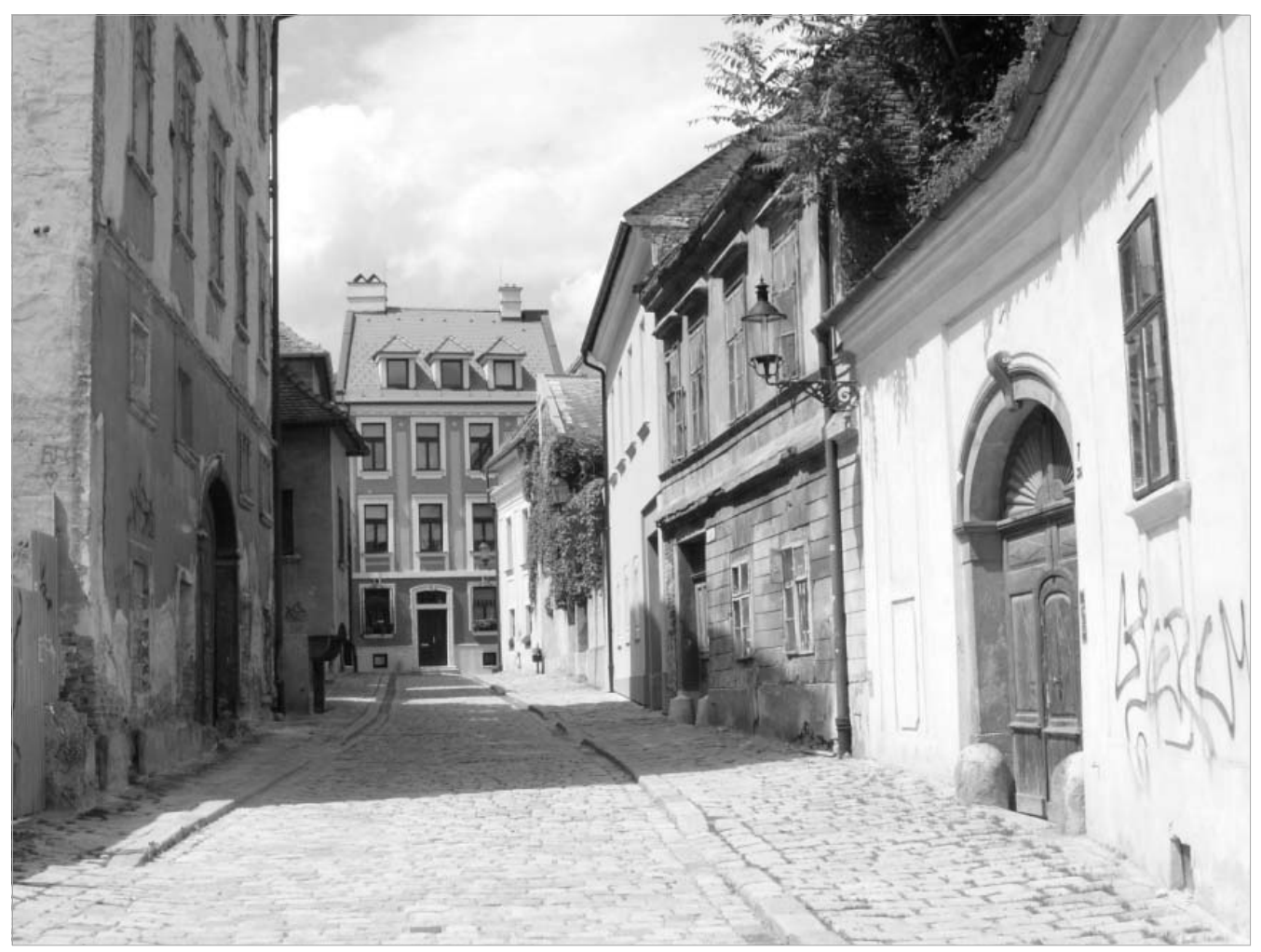

